\title{
MICROBIOLOGICAL EVALUATION OF PASTY AND SOFT ICE CREAM
}

\author{
Débora Rodrigues Silveira*1 \\ Thamíris Pereira de Moraes ${ }^{1}$ \\ Jennifer Scheffer de Oliveira' ${ }^{1}(\mathbb{C})$ \\ Cláudio Dias Timm ${ }^{1}$
}

SILVEIRA, D. R.; MORAES, T. P. de; OLIVEIRA, J. S. de; TIMM, C. D. Microbiological evaluation of pasty and soft ice cream. Arquivos de Ciências Veterinárias e Zoologia da UNIPAR, Umuarama, v. 24, n. 1 cont., e2404, 2021.

\begin{abstract}
Ice cream is susceptible to contamination by handling and bad hygiene conditions during both the storage process and the fractioning for sale, and once contaminated, it can cause diseases. The purpose of this survey was to evaluate the microbiological quality of ice cream sold in bulk, of pasty and soft types, offered for consuming. Thirty samples of pasty ice cream sold in bulk, and thirty samples of soft ice cream were analyzed through the counting of thermotolerant coliforms, coagulase-positive Staphylococcus spp., and searching for the presence of Salmonella spp. During the study, a total of ten $(33 \%)$ samples of pasty ice cream and five (16\%) samples of soft ice cream were found to be beyond the limits established by the Brazilian law. Salmonella spp. was found in four samples $(6.7 \%)$. These results are an alert for the need of greater attention to the microbiological quality of ice cream in order to ensure the safety of its consumers.
\end{abstract}

KEYWORDS: Coagulase-positive Staphylococcus spp. Pasty ice cream. Salmonella spp. Soft ice cream. Thermotolerant coliforms.

\section{AVALIAÇ̃̃O MICROBIOLÓGICA DE SORVETES PASTOSOS E EXPRESSOS}

RESUMO: Os sorvetes são suscetíveis à contaminação pela manipulação e más condições higiênicas durante o processamento, armazenamento e do fracionamento para venda, uma vez contaminados podem causar doenças. O objetivo deste estudo foi avaliar a qualidade microbiológica de sorvetes, vendidos a granel, pastosos e expressos, oferecidos para consumo. Trinta amostras de sorvete pastoso, vendido a granel, e trinta amostras de sorvete expresso foram analisadas realizando-se contagem de coliformes termotolerantes, Staphylococcus spp. coagulase-positiva e pesquisando-se a presença de Salmonella spp. Foram detectadas dez (33\%) amostras de sorvete pastoso e cinco (16\%) amostras de sorvete expresso fora dos limites estabelecidos pela legislação brasileira. Salmonella spp. foi encontrado em quatro amostras $(6,7 \%)$. Esses resultados alertam para a necessidade de uma maior atenção à qualidade microbiológica dos sorvetes, a fim de garantir a segurança do consumidor.

PALAVRAS-CHAVE: Coliformes termotolerantes. Salmonella spp. Staphylococcus spp. Coagulase positiva. Sorvete pastoso. Sorvete soft.

\section{EVALUACIÓN MICROBIOLÓGICA DE HELADOS PASTOSOS Y SUAVES}

RESUMEN: Los helados son susceptibles a la contaminación por manipulación y malas condiciones higiénicas durante el procesamiento, almacenamiento y fraccionamiento para venta, una vez contaminados pueden causar enfermedades. El objetivo de este estudio ha sido evaluar la calidad microbiológica de helados vendidos a granel, pastosos y suaves, ofrecidos para el consumo. Se analizaron treinta muestras de helados pastosos vendidos a granel, y treinta muestras de helados suaves, realizándose el conteo de coliformes termotolerantes, Staphylococcus spp. coagulase positiva e investigándose la presencia de Salmonella spp. Se detectaron diez (33\%) muestras de helado pastoso y cinco (16\%) muestras de helado blando fuera de los límites establecidos por la legislación brasileña. Salmonella spp. se encontró en cuatro muestras (6,7\%). Esos resultados destacan la necesidad de una mayor atención a la calidad microbiológica de los helados, con el fin de garantizar la seguridad del consumidor.

PALABRAS CLAVE: Coliformes termotolerantes. Salmonella spp. Staphylococcus spp. Coagulase positiva. Helado pastoso. Helado suave.

\section{Introduction}

Ice creams are products made basically with milk and/or dairy products and/or other alimentary raw resources, in which the fat content and protein are total or partly from not the milky origin, wich one can be by added other alimentary ingredients (BRASIL, 1999).

One of the fractionated ice creams commonly found in the retail market is the pasty type, sold in buffets, that can be manufactured artisanal, or industrially by the ice cream parlor itself, or by others. The ingredients are dosed, the bulk is pasteurized, after it's homogenized, matured, whipped so the air can be incorporated and lastly frozen (GOFF; HARTEL, 2013). The flavors are packed separately in large pots and are exposed on the buffets to be sold in fractions, suffering constant manipulation (GOTTARDI et al., 2008).

Another kind of ice cream is the soft one (or Italian) marketed through industrial mixtures, cooled and fractioned in a specific machine for this purpose. Generally, the points of sale are located on the street, in front of stores or cafes,

DOI: https://doi.org/10.25110/arqvet.v24i1cont.2021.8269

${ }^{1}$ Programa de Pós-Graduação em Veterinária - PPGV da Universidade Federal de Pelotas. Autor para Correspondência. Débora Rodrigues Silveira. debora. rsilveira@hotmail.com 
places, many times, with a lacking of drinking water to wash the equipment, utensils and for the consumer or the seller's hygiene (PARK et al., 2020).

Both ice creams types are susceptible to contamination by handling and bad hygiene conditions during the storage process and the subdivision for sale, once those can be means of diseases transmitted by food and water (DTFW) (RIZZO-BENNATO, 2004).

During the ice cream processing, the mixture is pasteurized, but this thermal treatment doesn't ensure that the final product is free of pathogens, because there are after-pasteurization steps that might lead to recontamination by microorganisms that can cause diseases. The frosting can reduce the bacterial population but doesn't ensure the sterilization, which means that some pathogens can keep themselves viable for long periods (COLLA; PRETICE-HERNANDEZ, 2003) and when they find good multiplication conditions, they reach the infecting dosage, causing gastroenteritis among consumers.

Salmonella spp., coagulase-positive Staphylococcus spp. and thermotolerant coliforms are microorganisms frequently isolated from milk and derivatives, that, for being broadly spread on nature, utensils, raw material and handlers, can contaminate the ice cream, offering riskiness to public health (DIOGO et al., 2002). From 2000 to 2010, two hundred and thirty-nine outbreaks involving 2,418 cases of gastroenteritis related to milk and dairy products consume were notified, in the state of São Paulo. From these outbreaks, seventy-nine $(33.3 \%)$ had the etiological agents identified. Sixty-seven (84.8\%) happened because of bacterial action, in which Staphylococcus aureus was responsible by sixteen (23.9\%), followed by Escherichia coli, with eleven (16.4\%) and Salmonella spp., associated to ten (14.9\%) outbreaks (MERUSSI; MAFFEI; CATANOZI, 2012).

This survey's objective was to evaluate the microbiological quality of ice creams sold in bulk, of the pasty and soft types, offered for consuming.

\section{Materials and Methods}

Thirty samples of soft ice creams and thirty of pasty ice creams marketed in bulk at fourteen selling points in Pelotas city, Rio Grande do Sul, were collected. From those samples, twenty-three were chocolate flavor, seventeen were strawberry, six were vanilla and fourteen were cream, as it was available at the selling points. The ice creams, in the original packaging, were cooled aseptically in sterile bags and immediately submitted refrigerated to the laboratory for analyses.

Counts of thermotolerant coliforms, count of Staphylococcus positive coagulase and the presence of Salmonella spp. were performed according to the methodology recommended by Timm, Lima and Cereser (2017). For the counting of thermotolerant Coliforms, briefly, samples of 25 $\mathrm{mL}$ of ice cream were diluted in $225 \mathrm{~mL}$ of $0.85 \%$ saline solution. Subsequently, inoculation was carried out in a series of three tubes of Sodium Lauryl Sulfate broth (Merck, Darmstadt, Germany). After $48 \mathrm{~h}$ of incubation, at $37^{\circ} \mathrm{C}$ the tubes with gas production were reseeded in Escherichia Coli broth (Himedia, Mumbai, Índia). After $48 \mathrm{~h}$ of incubation at $45^{\circ} \mathrm{C}$ the tubes with gas growth were considered positive and the reading was performed according to the Most Probable Number (MNP) table.

The counts of $S$. aureus was carried out by spreading the first and a second dilution in Baird-Parker agar surface (Himedia) and then incubating the plates at $37^{\circ} \mathrm{C}$ for $48 \mathrm{~h}$. Counts of the colonies was done, three typical and three atypical colonies of $S$. aureus were inoculated on a Brain and Heart Infusion broth (Himedia) and incubated at $37^{\circ} \mathrm{C}$ for 24 $\mathrm{h}$ to perform the coagulase test. In this test, $0.3 \mathrm{~mL}$ of culture were inoculated in $0.3 \mathrm{~mL}$ of blood plasma and for $6 \mathrm{~h}$ of incubation at $37^{\circ} \mathrm{C}$ the formation of clots was monitored.

To assess Salmonella, $25 \mathrm{~mL}$ of ice cream were inoculated in $225 \mathrm{~mL}$ of Buffered Peptone Water (Himedia) for pre-enrichment and remaining procedures, as recommended by Timm, Lima and Cereser (2017).

\section{Results and Discussion}

Being the ice cream classified as an eatable gelid, the results obtained with the samples evaluations were compared with the standards required at the Agência Nacional de Vigilância Sanitária (ANVISA) for these products, at the RDC n ${ }^{\circ}$ 12, from 2nd January, 2001 (BRASIL, 2001). Were found seven $(23 \%)$ samples of pasty ice cream and five $(16 \%)$ samples of soft ice cream out of the limits established by the legislation (Figures 1 and 2).

Figure 1. Results of the microbiological evaluation of 30 samples of pasty ice cream collected at the retail market from Pelotas city, RS, according to the RDC n ${ }^{\circ} 12 / 2012$ from ANVISA (BRASIL, 2001).

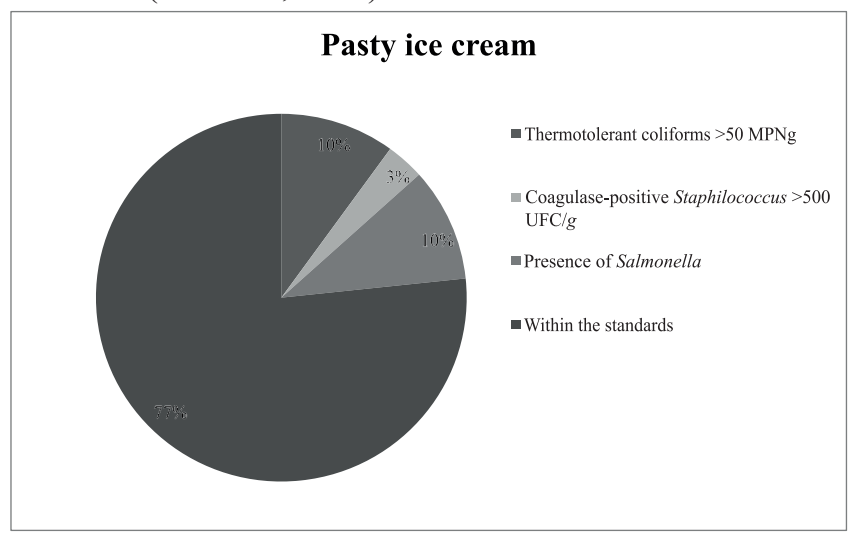

Figure 2. Results of the microbiological evaluation of 30 samples of soft ice cream collected at the retail market from Pelotas city, RS, according to the RDC n ${ }^{0} 12 / 2012$ from ANVISA (BRASIL, 2001).

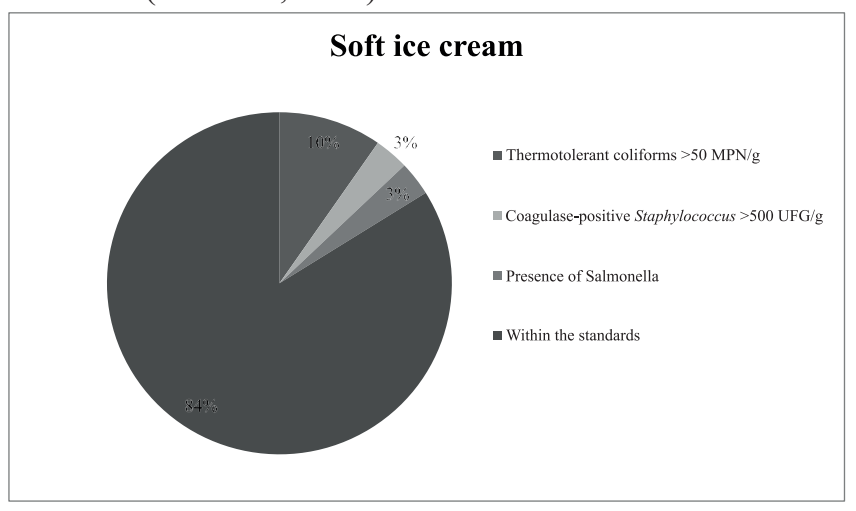


The caption can also be used to explain any acronyms used in the figure, as well as providing information on scale bar sizes or other information that cannot be included in the figure itself. Plots that show error bars should include in the caption a description of how the error was calculated and the sample size (Figure 2).

The four samples in which were detected the presence of Salmonella spp. were from the same ice cream parlor, one sample of soft ice cream and three samples of pasty ice cream commercialized in buffets. At this ice cream parlor, the same spoons were used for all flavors of ice creams at the buffet and stocked in a container with water. The fact that they were kept at this place and the constant manipulation by the handlers, can made this water be rich in nutrients from those ice creams, favoring the proliferation of microorganisms, as Salmonella spp. (MARQUES et al., 2005). Probably, this was a fundamental point in terms of bacterial contamination and dissemination on the ice creams commercialized in buffet. The presence of Salmonella spp. in one sample of soft ice cream at the same ice cream parlor that was isolated Salmonella spp. from the buffet, evidence that this pathogen was present in this environment. The contamination of this other product can be related to the own food, handlers, utensils, and the equipment used in common between these different ice cream types.

Studies realized in other states of the federation to determine the microbiological quality of ice creams didn't isolate Salmonella spp. from the samples analyzed (RIZZOBENNATO, 2004; SANTA et al., 2010, TONET et al., 2011). The four samples that contained Salmonella spp. were collected at the same ice cream parlor, which indicates inappropriate sanitary-hygienic care at the establishment.

Several serotypes of Salmonella spp. keep themselves viable for longs periods on dairy products, even in those that have an adverse environment to survival (SILVEIRA et al., 2012). This fact, associated with the importance of the bacteria as an agent of DTFW, makes its presence in the food unacceptable, even in low concentrations. In addition to the danger of Salmonella spp. being present, ice cream is commonly consumed by children, who present an immature immune system, therefore, they are more susceptible to infections (TONET et al., 2011).

The percentage of samples out of the standards for thermotolerant coliforms was 10\% (Figures 1 and 2), in other words, three samples of pasty ice cream and three samples of soft ice cream presented counts above to the stipulated from ANVISA. The counts reached $>110 \mathrm{MPN} / \mathrm{mL}$ in five of the samples cited, and in one sample of soft ice cream was found $110 \mathrm{MPN} / \mathrm{mL}$. In a similar study realized in Paraná, Fifteen samples of soft ice cream were analyzed, in which three obtained counts of thermotolerant coliforms above the acceptable and one contained coagulase-positive Staphylococcus spp. also out to the standards (SANTA et al., 2010).

In the study by Silva, Vidal and Junior (2016), three of nine samples of ice cream collected in four cities in the northeastern region of the State of São Paulo, presented thermotolerant coliform counts above the same limits used in this work. High scores of thermotolerant coliforms indicate precariousness hygienic-sanitary cares.

Both counts of coagulase-positive Staphylococcus spp. were above the standard, were $2.6 \times 10^{3} \mathrm{UFC} / \mathrm{mL}$ in one sample of pasty ice cream, and $1,7 \times 10^{3} \mathrm{UFC} / \mathrm{mL}$ in one sample of soft ice cream.

The importance of the presence of this microorganism in foods is related to its ability to produce enterotoxins. Although, it can vary according to the conditions and particularities of each food. An effective dose of enterotoxins can be produced when the population of $S$. aureus exceeds $10^{5}$ cells per gram of the food (BENNETT, 2005). The milk prevenient from cows affected by mastitis can deliver this microorganism and, in case it has not been correctly pasteurized, can remain viable in the final product (VIÇOSA et al., 2010).

The log three concentration observed in the two ice cream samples in which positive coagulase Staphylococcus was detected is not sufficient for the production of toxins, however, depending on the storage conditions of the ice cream, it is possible to multiply this pathogen, even reaching the concentration necessary for generate intoxication.

Besides, Staphylococcus spp. is an inhabitant of human's nostrils and is commonly found on our hands (SOARES et al., 2012). The self-service buffets, places where people usually talk in front of the exposed food while they are serving themselves, provide the contamination by oral and nostril bacteria through the droplet (MARRIOTT; ROBERTSON, 1997).

Both samples where coagulase-positive Staphylococcus spp. counts were found above $500 \mathrm{UFG} / \mathrm{g}$ were chocolate flavor (twenty-three collected samples $38.3 \%$ ). Thermotolerant coliforms were above the limit in six samples, in which four were cream (total of fourteen samples $-23.6 \%$ ) and two were chocolate. All vanilla samples (six $-10 \%)$ were inside the established standards. It doesn't seem to have a relation between the ice cream flavor and its contamination, however, for this possibility to be discarded, studies with a larger number of samples would be necessary.

Pasty ice cream showed a superior number of noncompliance before the ANVISA standards than the soft ones. This result can be assigned to the bigger handling and exposure of the products on buffets. Other possible contamination sources are the raw material, the bad water quality used for sanitation, pasteurization processes, bad preparation, temperature/cooling environment and inadequate storage.

\section{Conclusions}

The ice cream sold in Pelotas city, RS, both pasty and soft, might conduct undesirable microorganisms, including important pathogens in public health. The results of this study are an alert to the need of bigger attention by the regulatory agencies concerning the microbiological quality of the ice cream, once the adoption of hygienic and sanitary measures is essential for a safe product guarantee.

\section{Funding Information}

This work was suopported by the Coordenação de Aperfeiçoamento de Pessoal de Nível Superior (CAPES) Grant number 001. 


\section{References}

BENNETT, R. W. Staphylococcal enterotoxin and its rapid identification in foods by enzyme-linked immunosorbent assay-based methodology. Journal of Food Protection, Des Moinses, v. 68, n. 6, p. 1264-1270, 2005.

BRASIL. Agência Nacional de Vigilância Sanitária. Portaria $n^{\circ} 379$, de 26 de abril de 1999. Regulamento técnico para fixação de identidade e qualidade de gelados comestíveis, preparados, pós para o preparo e bases para gelados comestíveis. Diário Oficial da República federativa do Brasil, Brasília, 26 abr. 1999. Seção 1, p. 1-5. Disponível em: http://bvsms.saude.gov.br/bvs/saudelegis/ svs1/1999/ prt0379_26_04_1999.html. Acesso em: 15 maio 2021.

BRASIL. Agência Nacional de Vigilância Sanitária. Resolução - RDC n ${ }^{\circ} 12$ de 02 de janeiro de 2001. Regulamento técnico sobre padrões microbiológicos para alimentos. Diário Oficial da República federativa do Brasil, Brasília, 10 jan. 2001. Seção 1, p. 38-39. Disponível em: http://bvsms.saude.gov.br/bvs/saudelegis/ anvisa/2001/ res0012_02_01_2001.html. Acesso em: 15 maio 2021.

COLLA, L. M.; PRENTICE-HERNANDEZ, C. Congelamento e descongelamento: sua influência sobre os alimentos. Vetor, Rio Grande, v. 13, n. 1, p. 53-66, 2003.

DIOGO, G. T.; AGUIAR, G. M.; TOLENTINO, M. C.; BUFFARA, D.; PILEGGI, M. Avaliação microbiológica de sorvetes comercializados na cidade de Ponta Grossa - PR e da água usada na limpeza das colheres utilizadas para servilos. Publicatio UEPG. Ciências Biológicas e da Saúde, Ponta Grossa, v. 8, n. 1, p. 23-32, 2002.

GOFF, D. H.; HARTEL, R. W. The ice cream industry. In: GOFF, D. H.; HARTEL, R. W. Ice cream. United States: Springer, 2013. p.1-17.

GOTTARDI, C. P. T.; MOTTIN, V.; MÜRMANN, L.; SALDANHA, C. A.; SCHMIDT, V.; CARDOSO, M. Avaliação das práticas de fracionamento de produtos de origem animal em supermercados em Porto Alegre. Acta Scientiae Veterinariae, Porto Alegre, v. 36, n. 2, p. $167-$ $172,2008$.

MARRIOTT, N. G.; ROBERTSON, G. Essentials of food sanitation. Springer Science \& Business Media, 1997.

MARQUES, O. M.; PEREIRA, A. G.; SOBREIRA, A. D.; ALBUQUERQUE, S. S. M. C. D. Qualidade microbiológica da água de lavagem das conchas de aço inoxidável de sorveterias da cidade de Recife, PE. Higiene Alimentar, v. 19, n. 136, p. 96-100, 2005.

MERUSSI, G. D.; MAFFEI, D. F.; CATANOZI, M. P. L. Surtos de gastroenterite relacionados ao consumo de laticínios no estado de São Paulo no período de 2000 a 2010. Alimentos e Nutrição, Araraquara, v. 23, n. 4, p. 639-645, 2012.
PARK, J. M.; KIM, J. M.; HONG, J. W.; YOU, Y. H. Microbial control measures for soft ice cream in franchise brands: a comparative analysis of microbial analysis and manufacturing practices. Food Science \& Nutrition, v. 8, n. 3, p. 1583-1595, 2020.

RIZZO-BENNATO, Roberta Teresa. Qualidade microbiológica do leite e do sorvete de massa de uma indústria de pequeno porte do município de Piracicaba - SP. 2004. Dissertação (Mestrado em Ciência e Tecnologia de Alimentos) - Universidade de São Paulo, São Paulo, 2004.

SANTA, O. R. D.; JUSTUS, A.; ZANETTE, C. M.; CHACÓN ALVAREZ, D.; SANTA, H. S. D. Qualidade microbiológica de sorvetes tipo italiano, comercializados na cidade de Guarapuava, Paraná. Higiene Alimentar, v. 24, n. 180/181, p. 59-63, 2010.

SILVA, H. O.; VIDAL, A. M. C.; JUNIOR, O. D. R. Análises de coliformes totais e termotolerantes em produtos derivados lácteos e sorvetes. Ciência \& Tecnologia Fatec- JB, Jaboticabal, 8(esp.), 2016.

SILVEIRA, D. R.; LOPES, N. A.; GONZALEZ, H. D. L.; TIMM, C. D. Salmonella Typhimurium, Infantis, Derby, and Enteritidis survival in pasty dulce de leche. Ciência e Tecnologia de Alimentos, Campinas, v. 32, n. 4, p. 715-718, 2012.

SOARES, L. S.; ALMEIDA, R. C.; CERQUEIRA, E. S.; CARVALHO, J. S.; NUNES, I. L. Knowledge, attitudes, and practices in food safety and the presence of coagulasepositive staphylococci on hands of food handlers in the schools of Camaçari, Brasil. Food Control, v. 27, n. 1, p. 206-213, 2012

TIMM, Cláudio Dias; LIMA, Helenice Gonzalez de; CERESER, Natacha Deboni. Manual de técnicas microbiológicas em leite e derivados. Pelotas: Ed. do autor, $2017.85 \mathrm{p}$.

TONET, A.; RIBEIRO, A. B.; BAGATIN, A. M.; QUENEHENN, A.; SUZUKI, C. Qualidade microbiológica de sorvetes e caldas pasteurizadas produzidos artesanalmente em uma cidade do estado do Paraná. Revista Brasileira de Pesquisa em Alimentos, Campo Mourão, v. 2, n. 2, p. 96103, 2011.

VIÇOSA, G. N.; MORAES, P. M.; YAMAZI, A. K.; NERO, L. A. Enumeration of coagulase and thermonucleasepositive Staphylococcus spp. in raw milk and fresh soft cheese: An evaluation of Baird-Parker agar, Rabbit Plasma Fibrinogen agar and the Petrifilm ${ }^{\text {TM }}$ Staph Express count system. Food Microbiology, v. 27, n. 4, p. 447-453, 2010.

Recebido em: 03.12.2020 Aceito em: 02.06.2021 